\title{
The Trans-Pacific Partnership: Is It Everything We Feared for Health?
}

\section{Ronald Labonté, Ashley Schram, Arne Ruckert*}

\begin{abstract}
Background: Negotiations surrounding the Trans-Pacific Partnership (TPP) trade and investment agreement have recently concluded. Although trade and investment agreements, part of a broader shift to global economic integration, have been argued to be vital to improved economic growth, health, and general welfare, these agreements have increasingly come under scrutiny for their direct and indirect health impacts.

Methods: We conducted a prospective health impact analysis to identify and assess a selected array of potential health risks of the TPP. We adapted the standard protocol for Health impact assessments (HIAs) (screening, scoping, and appraisal) to our aim of assessing potential health risks of trade and investment policy, and selected a health impact review methodology. This methodology is used to create a summary estimation of the most significant impacts on health of a broad policy or cluster of policies, such as a comprehensive trade and investment agreement.

Results: Our analysis shows that there are a number of potentially serious health risks associated with the TPP, and details a range of policy implications for the health sector. Of particular focus are the potential implications of changes to intellectual property rights (IPRs), sanitary and phytosanitary measures (SPS), technical barriers to trade (TBT), investor-state dispute settlement (ISDS), and regulatory coherence provisions on a range of issues, including access to medicines and health services, tobacco and alcohol control, diet-related health, and domestic health policymaking.

Conclusion: We provide a list of policy recommendations to mitigate potential health risks associated with the TPP, and suggest that broad public consultations, including on the health risks of trade and investment agreements, should be part of all trade negotiations.

Keywords: Social Determinants of Health, Trade and Investment Policy, Population Health, Global Governance for Health

Copyright: (C) 2016 by Kerman University of Medical Sciences

Citation: Labonté R, Schram A, Ruckert A. The Trans-Pacific Partnership: Is it everything we feared for health? Int J Health Policy Manag. 2016;5(8):487-496. doi:10.15171/ijhpm.2016.41
\end{abstract}

\section{Article History:}

Received: 16 December 2015 Accepted: 12 April 2016 ePublished: 17 April 2016

\section{Key Messages}

Implications for policy makers

- There are numerous connections between trade and investment agreements, specifically the Trans-Pacific Partnership (TPP), and public health.

- Health impact assessment (HIA) methodology can be a valuable tool for exploring prospective health impacts of such agreements.

- Domestic health policy that is not compliant with trade rules is vulnerable to international trade disputes.

- There are opportunities for health policy-makers to play an active role in advocating for public health during domestic ratification of the TPP and to advocate for greater involvement in future trade negotiations.

Implications for the public

The content within contemporary trade and investment agreements goes far beyond the traditional trade agreement measures, such as cutting tariffs on goods, creating wide-reaching and long-lasting consequences for all aspects of life. The recently negotiated Trans-Pacific Partnership (TPP) will have implications for public health issues, such as pharmaceutical prices and food safety standards, and may divert public tax dollars away from the provision of public services to payment of investor-state dispute settlement (ISDS) legal services and awards. The general public was denied access to the draft texts during negotiations, despite abundant input from the private sector throughout the deal. All countries are currently undergoing domestic processes that will enable them to ratify the deal, many of which have begun a period of public consultation. The general public should use this time to learn about the implications of the deal and take this opportunity to advocate for their rights and demands.

\section{Background}

On the fifth of October 2015 negotiation of the Trans-Pacific Partnership (TPP) concluded, turning it from the biggest trade deal the general public had never heard of, ${ }^{1}$ to headline news overnight. The Agreement includes 12 Pacific Rim nations: Australia, Brunei, Canada, Chile, Japan, Malaysia, Mexico, New Zealand, Peru, Singapore, the United States, and Vietnam. Together these countries account for $40 \%$ of global gross domestic product (GDP) and $26 \%$ of global trade. ${ }^{2}$
Although trade and investment agreements, part of a broader shift to global economic integration, have been argued to be vital to improved economic growth, health, and general welfare, ${ }^{3}$ these agreements have increasingly come under scrutiny for their direct and indirect health impacts. A body of literature exploring the relationships between international trade and investment agreements and health has been accruing over the past few years. ${ }^{4-12}$ But with the exception of one of those studies, ${ }^{11}$ the literature to date has largely been 
conceptual in nature, and has rarely explored specific treaty text.

With the official release of the TPP text a month after negotiations concluded ${ }^{[1]}$, policy analysts could finally move past speculative assessments of the TPP's impacts for health and begin to unpack the world's largest free trade agreement. Existing analyses have thus far been conducted based on leaked texts only and have assessed a more limited number of health concerns related to the TPP. ${ }^{5,13-15}$ The following is a prospective health policy impact assessment of the TPP based on a range of potential public health risks introduced by previous assessments of leaked TPP text, and comparable existing agreements, to evaluate these concerns in light of the final text. Our analysis shows that there is a number of potentially serious health risks associated with the TPP, and details a range of policy implications for the health sector. We conclude with recommendations that could advise public consultations on the TPP to mitigate health risks. These recommendations are also meant to inform ongoing and future trade negotiations, given the increased recognition of the importance of policy coherence between international trade and investment agreements and domestic health policy.

\section{Methods}

The World Health Organization (WHO) defines health impact assessment (HIA) as "a combination of procedures, methods and tools by which a policy, program or project may be judged as to its potential effects on the health of a population, and the distribution of those effects within the population." ${ }^{16}$ We adapted the standard protocol for HIAs (screening, scoping, and appraisal) to our aim of assessing potential health risks of trade and investment policy. While HIAs are increasingly used to evaluate the health effects of a diverse range of non-health policies, their application within foreign policy is very new, ${ }^{17}$ with only two HIAs of regional trade and investment agreements published thus far. ${ }^{14,18}$

\section{Screening}

In the HIA process, screening identifies potential links between the policy, program, or project, and the impacts it may have on health based on available opinion and evidence. We started by searching for key health risks related to TPP provisions within academic and civil society discourse. We found that previous analyses had highlighted potential implications of intellectual property rights (IPRs), investorstate dispute settlement (ISDS), technical barriers to trade (TBT), sanitary and phytosanitary measures (SPS), and regulatory coherence provisions on a range of issues, including access to medicines and health services, tobacco and alcohol control, diet-related health, and domestic health policymaking. ${ }^{5,6,11,19-22}$ We screened several additional sections of the agreement, including provisions on trade in goods, trade in services, government procurement, labour, environment, and transparency and anti-corruption.

\section{Scoping}

The next stage of the HIA is scoping which involves deciding which health effects to investigate, in which populations, and by which methods. Additionally, it requires selecting one of three approaches: (1) a rapid health impact appraisal;
(2) a health impact analysis; or (3) a health impact review. ${ }^{16}$ The first approach is a systematic assessment of the policy by experts and stakeholders in a short duration, while the second approach is a comprehensive assessment of the policy including a review of the available evidence, stakeholder opinions and expectations, and, if needed, production and analysis of new data. We selected the third approach, a health impact review, as it is the suggested method when in-depth analyses are not feasible because the policies under consideration are exceptionally broad, an appropriate selection for a review of a comprehensive regional trade and investment agreement. The goal of this approach is to create a "summary estimation of the most significant impacts on health of the policy or cluster of programmes and projects, without necessarily trying to disentangle the precise impact of the various parts of the policy or cluster on specific aspects of health...to give a broad-brush view of the impact" (p.7). ${ }^{16}$ In the scoping stage, we elected to address the chapters identified in the literature at the screening stage. We limited our review to potential health risks, rather than potential health benefits, as one measure to keep the volume of work within scope for this review. We elected not to include a review of trade in goods or trade in services as each area includes a series of annexes and side letters on country-specific commitments, including customised tariff reduction phasein schedules and non-conforming measures that would make general impacts on health especially problematic to forecast. Additionally, the threats to health from trade in goods and services have long been a part of an increasingly integrated global economy, making changes directly attributable to the TPP difficult to surmise. The Government Procurement, Labour, and Environment Chapters were omitted given the length limitations of this article and because we currently have additional articles under review with different journals covering this area of interest. Finally, we scanned the Transparency and Anti-Corruption Chapter for relevant intersections with the Chapters included in this review.

To increase the generalisability of our health policy impact review, we did not narrow our investigation of implications to any single population, or any single TPP country; however, we did at times consider specific vulnerabilities for developing country members of the TPP. Finally, our selected method for the appraisal stage was a prospective policy analysis (PPA) which explores future impacts of policy change $\mathrm{e}^{23}$ based on existing expert knowledge and information gained from previous similar exercises and research. PPA has previously been used to explore the impacts of a bilateral trade agreement on a set of health policy goals. ${ }^{11}$

Results

The following appraisal reviews the final text of the TPP for potential implications of IPRs, SPS, TBT, ISDS, and regulatory coherence provisions on a range of issues, including access to medicines and health services, tobacco and alcohol control, diet-related health, and domestic health policy-making.

\section{Intellectual Property Rights}

One of the longest standing public health concerns with postWorld Trade Organization (WTO) trade and investment agreements has been their potential impact on the price of 
pharmaceuticals. From the outset of TPP negotiations it was expected that IPRs would reflect the interest of the American pharmaceutical industry to extend patent protection and other measures that delay the entry of generic drugs into the market. The final IPR Chapter mitigates some, but not all, of these concerns, excluding some of the more contentious provisions in the leaked drafts, such as allowing patenting of new surgical techniques. The TPP adopts the WTO TradeRelated Intellectual Property Rights (TRIPS) Agreement provision that allows Parties to exclude from patentability "diagnostic, therapeutic and surgical methods for the treatment of humans or animals" (art.18.37, q3).

The TPP is the first trade agreement to include provisions on pharmaceuticals that are, or contain, biologics, compounds produced through biological processes and which are used primarily for treating cancer and immune conditions. Biologics are costly to research and this expense is passed on to patients or their insurers, with some cancer drugs estimated to cost over $\$ 100000$ per year per patient. ${ }^{24}$ Monopolies for biologics are more effectively maintained through data exclusivity measures than the traditional patent system, given the difficulty in replicating the biologic process. Biosimilars or subsequent entry biologics are not generic products in the traditional sense $\mathrm{e}^{25}$; data protection provisions can offset potentially less secure protection offered by patents. The United States had wanted market exclusivity on biologics for 8 to 12 years, using clinical trial data protection as one of the means to do so. The final IPR Chapter (art.18.52, \1) provides market exclusivity through data protection for at least 8 years, although it also provides Parties with the option of only 5 years protection as long as other measures "deliver a comparable outcome in the market," ie, 8 years. The reason for this ambiguous wording is reportedly due to a political compromise reached between the United States and Australia in the last days of the negotiation in order to secure the Agreement, due to Australia's refusal to agree to a data-exclusivity period of greater than 5 years. ${ }^{26}$ The impact of this provision on public and private costs for biologics is likely to be steep. The Chapter does affirm that, with respect to biologics, "a Party may take measures to protect public health in accordance with...the Declaration on TRIPS and Public Health" (art18.50, \3). Provisions in this Declaration allow countries to issue compulsory licences ${ }^{[2]}$ for production of generic equivalents of patented drugs, lowering the price and increasing accessibility. Explicit reference to the Declaration on TRIPS in the TPP represents a small window of potential policy flexibility and a victory for public health that lobbied for its inclusion. Such provisions, however, have rarely been used apart from a brief post-Declaration period where most such licences were issued for drugs to treat HIV/AIDS. ${ }^{27}$ One could expect the United States to pressure countries into avoiding doing so in the case of biologics.

There are several other provisions in the Chapter that could affect the price of medicines. Art.18.37, $₫ 1$ allows for patenting of existing pharmaceuticals for "new uses, new methods of using...or new processes," a TRIPS+ provision that can offer increased patent protection without the requisite innovation patents are designed to reward. Throughout the TPP's negotiating period Médecins Sans Frontières (MSF) was critical of the impact extended patent terms would have on access to medicines, especially for developing countries. The TPP also requires Parties to provide patent term adjustments (extensions) to compensate for "unreasonable delays" in a government issuing a patent (art.18.46, \3). Patent term extensions were never part of the original TRIPS Agreement, and function to delay generic competition. The TPP is silent on the actual length of a patent term extension ${ }^{[3]}$ if an 'unreasonable delay' is encountered, which could provide Parties with flexibility for a short period or drug companies with cause to initiate a dispute for longer ones. Four TPP countries, Malaysia, Mexico, Peru, and Vietnam, fall well below the economic development levels of high-income Parties and have been given a longer period in which to incorporate the TPP's stringent IP provisions (3 to 10 years), although the use of set time periods takes no account of the actual development level or capacity of such countries to comply with their new IPR obligations.

The TPP Chapter on Transparency and Anti-Corruption also contains provisions that apply to pharmaceuticals. A leaked draft Annex to this Chapter (Annex 26-A) had raised concerns about the ability of TPP countries with national healthcare programs (the United States, New Zealand, Australia, and Japan) to control or otherwise limit the costs of products on their covered drugs and medical devices lists. ${ }^{28}$ There was considerable lobbying from within and outside of the negotiations to limit the ability of industry to affect the functioning of these national programs. These efforts resulted in several successes. Footnotes 11 and 12 in the final Annex clearly exclude government procurement and post-market subsidisation of pharmaceutical products and medical devices, including formulary management and development. This applies only to direct government procurement, however, and not to subsidy programs for private purchasers.

At the same time, the Annex imposes more onerous reporting, consulting, and administrative requirements that apply to all Parties, including those that may, in the future, develop a national reference price system for drugs and medical devices. These additional implementation costs could be a deterrent for such reforms, particularly for developing country members of the TPP. The Annex requires Parties to permit pharmaceutical manufacturers to disseminate information via the internet to health professionals and consumers, the controversial 'direct to consumer' advertising that has often been found to be deceptive. ${ }^{29}$ This provision will be subject to each Party's "laws, regulations and procedures" including any existing bans or restrictions on such marketing ( $\mid$ A.3); however, in the case that a TPP country introduces a new prohibition or limitation on such dissemination this may be vulnerable to dispute.

\section{Sanitary and Phytosanitary Standards}

While the inclusion of an SPS Chapter in the TPP was publicly known, projected concerns for food safety were made in general terms. The SPS Chapter in the TPP is intended to "reinforce and build on the SPS Agreement" (art.7.2b) within the WTO, the governing Agreement on food safety for traded goods which, in turn, defers to the Codex Alimentarius Commission for international standards. The Codex is tasked with two objectives, to protect the health of consumers and ensure fair practices in food trade. This stands in contrast to 
the stated objective of the SPS Chapter, to "protect human, animal, and plant life or health in the territories of the Parties while facilitating and expanding trade by a variety of means to seek to address and resolve sanitary and phytosanitary issues" (art.7.2a, our emphasis). The Codex was never intended to 'facilitate' and 'expand' trade, only to ensure that trade practices were fair and protected human health first and foremost.

The requirements for a Party to implement protections that exceed international standards has also been changed by the TPP. The WTO SPS Agreement acknowledged that, "Members may introduce or maintain sanitary or phytosanitary measures which result in a higher level of sanitary or phytosanitary protection than would be achieved by measures based on the relevant international standards, guidelines or recommendations, if there is a scientific justification" (art.3.3). The language of the TPP's SPS Chapter states instead that, "Each Party shall ensure that its SPS either conform to the relevant international standards, guidelines or recommendations or, if its SPS do not conform to international standards, guidelines or recommendations, that they are based on documented and objective scientific evidence" (art.7.9, our emphasis). While the WTO SPS leads with a permissive statement that states are able to implement higher protections, the TPP SPS highlights the importance of conformity to international standards. Moreover, if a country elects to enforce standards that exceed the requirements of international standards, the burden for doing so shifts from a 'scientific justification' to one 'based on documented and objective scientific evidence.' Under the WTO Agreement 'scientific justification' has been found to allow measures that are based on a minority scientific opinion ${ }^{30}$ which has been pivotal in permitting the implementation of the precautionary principle, something the TPP may undermine. The effect of this can only be fully understood after disputes have been raised and resolved under the TPP's SPS Chapter and contrasted with those of the WTO's SPS Agreement. However, it is reasonable to assume that the TPP's SPS Chapter has qualitatively raised the bar for the burden of scientific evidence required to introduce domestic food safety protections that exceed international standards.

Further to this point, the TPP SPS Chapter has created a system for Cooperative Technical Consultations for Parties to discuss matters under the Chapter that may adversely affect trade, which must be pursued before Parties are able to seek dispute settlement. That all communications and documentation generated during a Consultation are kept confidential, unless otherwise agreed by the Parties, has created a concern that the Parties' discourse on understandings of 'science' will be appropriated as confidential information. ${ }^{31}$ This provision also seems to be a contradictory sentiment to another TPP Chapter on Transparency and Anti-Corruption which states that "Each Party shall ensure that its laws, regulations, procedures and administrative rulings of general application with respect to any matter covered by this Agreement are promptly published or otherwise made available in a manner that enables interested persons and Parties to become acquainted with them" (art.26.2, ๆ1).

Many observers expected the TPP Agreement to set standards and procedures for biotechnological advances in food production, including policies on genetically modified organisms (GMOs). However, the SPS Chapter in the TPP, the raison d'etre of which is to address matters of trade and food safety, which consequently has wide significance for GMO products, ${ }^{32}$ made no reference to GMOs. In an interesting turn of events the negotiators located Trade in Products of Modern Biotechnology for agricultural goods in the TPP Chapter on National Treatment and Market Access for Goods, agreeing that "nothing in this Article shall require a Party to adopt or modify its laws, regulations, and policies for the control of products of modern biotechnology within its territory" (art.2.29, $\Phi \rrbracket 2-3$ ). However, this applies only to the content of this specific article, which focuses primarily on "inadvertent low level presence" of GMOs permitted in the exporting, but not the importing, country. It does not preclude new measures through which GMO exporting countries could exert pressure on TPP member states holding to a 'zero tolerance' policy for such products. $^{32}$

One such measure is likely to be the creation of a Working Group "for information exchange and cooperation on trade-related matters associated with products of modern biotechnology" (art.2.29, ๆ9). All Parties are able to "name one or more representatives to the Working Group." It would not be unreasonable to suggest that Parties may allow representation to include corporations that receive direct financial benefit from the development and distribution of biotechnology in agriculture, perhaps representatives from companies like DuPont, Cargill, and Dow Agro-Sciences which all acted as private corporate advisers to the United States during negotiations. ${ }^{33}$

\section{Technical Barriers to Trade}

Several concerns were raised around the TBT Chapter guaranteeing avenues for vested interests to have a legitimised role in policy-making, and further reducing the capacity for domestic innovation in tobacco, alcohol, and food labelling policies. ${ }^{5,11,19}$ The final text of the TBT appears to deliver on these concerns. The terms of this Chapter are extensive and largely speak to harmonisation and transparency in the development of technical regulations, standards, and conformity assessments, arguably to the benefit of big industry rather than states.

The Chapter includes a provision that "nothing in this Chapter shall prevent a Party from adopting or maintaining technical regulations or standards, in accordance with its rights and obligations under this Agreement, the TBT Agreement and any other relevant international obligations" (art.8.3, \5). The first part of this provision gives the impression that there will be protection of domestic policy space and national sovereignty, but the second part immediately limits those actions to those in accordance with the obligations of the Agreement. In plain language such obligations mean that Parties can do whatever they like as long as it does not violate anything in the Agreement. The Chapter also includes a provision that "The Parties shall cooperate with each other, where feasible and appropriate, to ensure that international standards, guides and recommendations that are likely to become a basis for technical regulations and conformity assessment procedures do not create unnecessary obstacles to international trade" (art.8.5, ๆ3, our emphasis). Under the 
WTO's TBT Agreement, dispute settlement panels, when weighing the necessity of regulations, refer to international standards. These standards were designed to protect things like consumer health and safety or the environment. The TBT provision in the TPP suggests that new international standards should be designed a priori to be least trade restrictive, in practice limiting any new protective standards to those that have already been vetted as trade-compliant.

Moreover, the TBT Chapter creates new avenues for vested interests to participate in regulation-setting, including the provision that, "Each Party shall allow persons of the other Parties to participate in the development of technical regulations, standards and conformity assessment procedures by its central government bodies...on terms no less favourable than those it accords to its own persons" (art.8.7, 91). According to the general definitions of the Agreement a person of a Party means a national or an enterprise of a Party (art.1.3), meaning persons would include multinational corporations that can claim nationality of that Party. Such provisions substantiate earlier concerns over the potential for regulatory capture ${ }^{19}$ or delays in developing new regulations and standards. The Chapter further seeks to have such rules extend outside state decision-making, adding that "Where appropriate, each Party shall encourage non-governmental bodies in its territory to observe the requirements" (art.8.7, 93). In Canada, this may apply to Crown corporations which are not technically governmental bodies, such as the Standards Council of Canada. This Council's mandate is to promote efficient and effective voluntary standardization in Canada, where standardization is not expressly provided for by law, and represents Canada's interests in standards-related matters in foreign and international forums.

The TBT Chapter also introduces new delays and administrative encumbrances in policy-making, such that "Each Party shall normally allow 60 days...for another Party or an interested person of another Party to provide comments in writing on the proposal" (art.8.7, -10); and that, "Each Party is encouraged to provide sufficient time between the end of the comment period and the adoption of the notified technical regulation or conformity assessment procedure for its consideration of, and preparation of responses to, the comments received" (art.8.7, \11).

Finally, the TBT Chapter introduces the first ever Annex on Proprietary Formulas for Prepackaged Food and Food Additives (Annex 8-F). The Annex is brief but may make it more challenging for governments to acquire information on proprietary formulas, introducing the restriction that the Parties shall "ensure that its information requirements are limited to what is necessary to achieve its legitimate objective" (art.3a). However, when it comes to proprietary formulas, states may not even know which questions to ask, let alone be able to defend those questions as necessary to legitimate objectives. Moreover, what constitutes a 'legitimate objective' would, if it becomes a matter of dispute, be subject to interpretation by dispute panellists or ISDS tribunal members, and not by food policy experts.

Investor-State Dispute Settlement

ISDS provisions in bilateral and regional trade agreements have generated widespread criticism and public health concern in recent years. Investment treaties and ISDS mechanisms that allow private investors to directly sue a government for compensation of losses (including anticipated future revenues) attributable to government measures are not new. However, the number of disputes, and the proportion being decided in favour of investors, has risen dramatically in the past decade, ${ }^{34}$ as has the monetary value of awards made by ISDS arbitration panels. A 2013 review of 196 ISDS claims found that 40 involved health or environmental protection, ${ }^{35}$ including measures concerning food safety, pharmaceuticals and tobacco control measures. Most of the environmental disputes, over water, land-use, pollution control and hazardous waste, have important indirect health implications. The high costs of defending against a dispute ${ }^{[4]}$, and the difficulty in knowing how a tribunal will rule in a case, are thought to contribute to 'regulatory chill', in which governments become more reluctant to enact new policy for fear of being sued. ${ }^{37}$ The current system for ISDS has been criticised for continuing to lack a coordinating body, a mechanism for political oversight, rules on transparency, and legal processes to correct incorrect decisions..$^{38}$ Arbitrators, in turn, have been criticised for creating a multimillion-dollar industry that they have promoted as necessary to attracting foreign direct investment, about which they have controlled the academic discourse and lobbied against reforms, and within which they have acted as negotiator, litigator, and arbitrator. $^{39}$

Exceptions in the Investment Chapter suggest that governments do not fully trust these rules to provide adequate policy protection. Important to health is one such exception, allowing Parties to exclude any tobacco control measure from an investment dispute (art.29.5). This exception was the result of strong public health lobbying to prevent the TPP from being yet another treaty that could be used by tobacco transnationals to challenge tobacco regulations, as Philip Morris has done in challenging Australia's tobacco plain packaging law and Uruguay's health warning regulation under other investment treaties, with some countries initiating additional state-tostate disputes under the WTO ${ }^{[5]}$ The 'tobacco exceptionalism' in the TPP, of course, will not prevent health regulations related to food, alcohol, or other health-harmful products from being challenged by investors. Neither will the TPP exception prevent investment challenges to tobacco control in the future using other agreements. Tobacco transnationals remain free to treaty-shop regardless of what the TPP prohibits, although this strategy was unsuccessful for Philip Morris in their claim against Australia plain packaging law, which was dismissed on jurisdiction. Finally, it is important to note that tobacco companies may still have input in the policy process through provision outlined in the transparency and regulatory coherence chapters, and that there can still be state to state tobacco disputes even where a state has exercised the option to block ISDS.

The fair and equitable treatment (FET) obligation is an ambiguous investor right, and the one most frequently invoked by investors. It is also the claim they are most likely to succeed on where all other claims have failed. ${ }^{40}$ It has been interpreted by tribunals to include increasingly expansive obligations for government. The TPP Investment Chapter appears to constrain FET, stating that "the mere fact that a 
Party takes or fails to take an action that may be inconsistent with an investor's expectations does not constitute a breach of this Article, even if there is loss or damage to the covered investment as a result” (art.9.5, -4). This means that an investor's expectations of future earnings alone are insufficient cause for a claim, ${ }^{41}$ a modification to treaty text that attempts to address concerns with previous awards. One such example was a 2015 NAFTA award in Bilcon v. Canada, in which an American investor argued that an environmental review that denied its proposed quarry was discriminatory, since other quarry applications by Canadian firms had been approved. Two of the three tribunal members ruled that the environmental decision frustrated the investor's "legitimate expectations," thereby violating NAFTA's FET obligation (despite such wording not actually appearing in NAFTA). The investor sought US\$300 million in damages, although an award has yet to be made. The third tribunal member strongly disagreed with this interpretation, arguing that the decision "will create a chill on the operation of environmental review panels," ${ }^{2}$ but in ISDS tribunals majority decisions are binding. Annex 9-B to the Chapter contains limitations on indirect expropriation, which refers to "an action or series of actions by a Party [that] has an effect equivalent to direct expropriation without formal transfer of title or outright seizure" (Annex 9-B, 93). The determination of indirect expropriation in a dispute has to consider, amongst other factors, "the extent to which the government action interferes with distinct, reasonable investment-backed expectations" (Annex 9-B, ๆ3 (a) (ii)). Within a footnote it is clarified that "[f]or greater certainty, whether an investor's investment-backed expectations are reasonable depends, to the extent relevant, on factors such as whether the government provided the investor with binding written assurances and the nature and extent of governmental regulation or the potential for government regulation in the relevant sector." The language of the footnote, that it includes 'factors such as', implies that this is not intended to be an exhaustive list, which does not adequately address concerns about ambiguity in what tribunals will be able to consider as additional factors forming legitimate expectations.

Government claims that the TPP ensures their right to regulate in the public interest is also questionable. This claim is based on Article 9.15, that, "nothing in this Chapter shall be construed to prevent a Party from adopting, maintaining or enforcing any measure otherwise consistent with this Chapter that it considers appropriate to ensure that investment activity in its territory is undertaken in a manner sensitive to environmental, health or other regulatory objectives." Unfortunately, the phrase 'otherwise consistent with this Chapter' means that governments can regulate in the public interest only if they comply with all of the other obligations in the Investment Chapter. Thus, governments are not, in fact, protected from state-state or investor-state disputes arising from regulatory changes they may undertake to protect environment, health or any other public purpose.

Similar to other new investment agreements, the Chapter includes IPRs in its definition of an investment, thus patented pharmaceuticals fall under its provisions. Extending TPP ISDS to more countries, including Japan which has its own pharmaceutical industry, could increase drug-related disputes similar to the one Canada is now facing with Eli
Lilly. Canada's 'promise of patent' rule led to Canadian courts revoking patents on two of Eli Lilly's drugs because they failed to fulfill the promise of increased utility made at the time of patent filing. After losing in Canadian courts, the company turned to NAFTA's ISDS rules and is seeking US\$500 million in compensation. There is one article in the TPP's IPR Chapter which allows a patent to "be cancelled, revoked or nullified" but "only on ground that would have justified a refusal to grant the patent" (art18.39, $\mid 1)$. This article appears to support Canada 'promise of the patent' rule that is the subject of the Eli Lilly dispute, although it does not, in itself, prevent a challenge from arising; nor is it known how this article might be interpreted by a tribunal should a similar dispute arise under the TPP.

While some progress has been made on issues of transparency of investment tribunals, many concerns remain unaddressed in the TPP. Although the Investment Chapter includes a provision for amicus curiae ('friend of the court') submissions from third parties "regarding a matter of fact or law" (art.9.22, \3), there is nothing binding on a tribunal to allow such submissions or to take them into account in their rulings. The Chapter, while recognizing that information presented before a dispute panel should be governed by governments' own information laws, calls on governments to "endeavour to apply those laws in a manner sensitive to protecting from disclosure information that has been designated as protected information" (art.9.23, ๆ5).

Finally, the TPP Parties have agreed to create a 'Code of Conduct' for ISDS arbitrators. As this is still to be drafted, its content is unknown; a point we return to later in this article.

\section{Regulatory Coherence}

The leaked draft of the Regulatory Coherence Chapter prompted concerns of a pro-industry approach to domestic policy and regulation, including new avenues for private actor involvement in the policy process. ${ }^{20}$ Although the treaty text (both the leaked and final version) acknowledges "each Party's sovereign right to identify its regulatory priorities and establish and implement regulatory measures to address these priorities, at the levels that the Party considers appropriate" (art.25.2, $\mid 2 \mathrm{~b}$ ), the language used to preface this, that they "affirm the importance of" such rights, gives the impression of a platitude.

Several provisions within the Chapter will increase the burden on domestic regulatory systems. Article 25.3, for example, requires that within one year after entry into force in their territory, each Party must "make publicly available the scope of its covered regulatory measures...each Party should aim to achieve significant coverage." In addition, there are provisions that Parties will create processes or mechanisms to facilitate interagency consultation and coordination (art.25.4, ๆ1), as well as review at intervals it deems appropriate its covered regulatory measures to determine if they "should be modified, streamlined, expanded, or repealed" (art.25.5, ๆ6). Current domestic procedures in each of the TPP member countries will dictate the level of challenge in introducing such measures, although it is reasonable to believe that the lower-income members of the Agreement will have reduced human resources for such administrative tasks and will bear a disproportionate burden during implementation. 
Whether the Regulatory Coherence Chapter will permit industry manipulation of domestic regulatory systems is open for debate. Provisions which reinforce that the TPP's Committee on Regulatory Coherence (\$25.6) "shall... provide opportunities for interested persons of the Parties to provide input on matters relevant to enhancing regulatory coherence" ( |25.8), and will take into account such input in the development of regulatory measures, de jure opens the door to all individuals. Whether industry, de facto, will be the only group to take advantage of this remains to be seen. Similarly, the prescribed interagency coordination may improve domestic policy coherence between health and trade objectives; however, if representatives from industry, finance, and trade are reviewing policies within health and the environment without a reciprocal exchange, then positive outcomes for health and environmental protection are less likely. The inclusion of a Regulatory Coherence Chapter is still new to trade and investment agreements, and no agreement currently in force contains one, thus time will be needed to understand the public health regulatory impact of its content. However, the exclusion of any matter under the Regulatory Coherence Chapter from challenge under dispute settlement procedures (art.25.11) is a win for public health.

\section{Discussion}

Our health impact review of the TPP demonstrates that most of the concerns of the public health community raised during the negotiation process have not been addressed in the final TPP text. The IPR provisions are likely to contribute to rising pharmaceutical prices, particularly for biologics, threatening affordable access to essential medicines in TPP countries. Key mechanisms include longer protection for clinical trial data, weaker requirements for new patents on old drugs, and threats to government-sponsored pharmaceutical benefit schemes. What is more, given that drug costs represent a significant share of public expenditure in some TPP countries, an increase in spending in this area may lead to cuts in social spending in other, potentially health-sensitive, areas.

While the SPS and the TBT Chapters within the TPP go slightly further than the original WTO Agreements in some respects, it is important to note that their general approach is already well-enshrined in the WTO's TBT and SPS Agreements. However, provisions in the TPP's SPS Chapter are likely to increase the burden of scientific evidence required for food safety standards, challenging the use of the precautionary principle in health, while new private committees established to discuss potential disputes in this area are moving away from transparency in policy-making. The TBT Chapter, in an effort to create regulatory harmonisation, has introduced new opportunities for private actor involvement in policymaking and policy delays due to administrative demands, while failing to adequately protect health policy space. What is more, the TBT Chapter is seeking to design international standards a priori to be compliant with trade aims and rules. The Regulatory Coherence Chapter amplifies these same concerns, introducing new outlets (or cementing such outlets in countries where they already exist) for private sector participation in policy-setting and administrative burdens on TPP governments specific to regulatory policy. Inclusion of ISDS mechanisms in the Investment Chapter without addressing concerns regarding the constructive ambiguity of investor rights or the issues of transparency and conflict-ofinterest in the arbitration system continue to leave signatory states vulnerable to expensive litigation and potential regulatory chill. More empirical research is needed, however, to assess the extent to which regulatory chill limits health policy space in practice, as there are still few such studies in this area.

In light of the material above, we have several recommendations for countries undergoing domestic processes to bring the TPP into force to mitigate the potential health risks introduced by this Agreement. These recommendations are generalizable to ongoing and future trade and investment negotiations, and directly relate to some of the recommendations that have recently emerged in the global governance for health literature, including concerns for representing health interests in non-health global governance venues and the need for multi-level governance mechanisms to replicate the shift from the multilateral to the bilateral/regional level in trade negotiations. ${ }^{43,44}$

The first recommendation is that more comprehensive assessments of the health impacts of the TPP should be conducted in the near future, including on Chapters that were omitted from this truncated review, such as government procurement, labour, environment, goods and services. Such assessments should explore both positive and negative potential health impacts. Our next recommendation is very broad: governments should ensure they provide adequate time for their ministries, and interested groups of the general public, to consider the potential impacts of this and similar agreements. The TPP is over 6000 pages and will have consequences for decades to come, as well as setting a precedent for future '21st century' agreements. Such a document is thus deserving of a transparent public consultation process of substantial length to ensure that all governments read carefully and act cautiously. In future negotiations, transparency and public consultation during the negotiation process, and increased access for public health experts and other groups interested in protecting general welfare, is needed. Since agreements such as the TPP no longer concern simply trade in goods and services, but 'behind the border' regulatory regimes, participation in framing negotiations and discussing particular articles and their commitments should not be restricted to private economic actors alone.

The third recommendation is to adequately address the concerns that have been raised around the current international arbitration system, including transparency and conflicts of interest. The European Commission (EC) has proposed new provisions for ISDS in their ongoing bilateral negotiations with the United States. The EC proposes an 'investment court system' (ICS) which would include 15 'judges' (5 each from the EU, the United States, and all other regions) appointed to serve as tribunal members. Unlike current ISDS tribunals, where each side chooses an arbitrator who then choose a third member, the ICS judges would be appointed at random, removing at least one source of bias in the present system. The EC proposal also calls for creation of an Appeal Tribunal to hear appeals on initial dispute rulings, similar to the functioning of the Appellate Body of the WTO; and prevents appointed judges from acting as counsel or 
witness in any other investment dispute. These provisions are marked improvements. Its Annex II on a Code of Conduct, however, is little more than exhortations to good behaviour by judges; and unless the TPP adopts more of the structural features of the ICS, adopting its Code of Conduct alone would do little to overcome the flaws in the current system ${ }^{[6]}$. Until these points are clarified through public scrutiny of the tobe-drafted TPP Code of Conduct, governments should not take steps to complete domestic processes towards bringing the Agreement into force. Moreover, if countries have been given the option, at any time, to exclude tobacco control from ISDS, it is reasonable to challenge governments on why the same option is not extended to any non-discriminatory health or environmental regulation or control measure. More fundamentally, where is the evidence that such investor powers and guarantees are needed to fulfill the initial intent of investment agreements: to prevent direct or indirect government expropriation of an investor's assets in the absence of a fair and transparent judicial system?

With respect to the SPS and TBT Chapters, it is not clear why more obligations than those in existing WTO SPS and TBT Agreements are needed. The best public health option here is to urge removal of these Chapters from the TPP, or for Parties to incorporate exclusions to any new provisions in these Chapters that exceed those in the WTO Agreements. It is more difficult to consider how the new Regulatory Coherence Chapter should be amended, although seeking immediate public commitment from the governments of each Party that public health and civil society groups, as 'interested persons of the Parties', shall, at a minimum, have at least equal representation in providing input into regulatory coherence as that provided by industry groups, and that all such input be transparent and publicly accessible.

There are three general conclusions about the TPP that can be made, albeit with the usual caveats about the risk of prediction. First, the TPP cannot come into force for any country unless the United States completes its domestic processes to bring the TPP into force. Second, domestic governance rules in the United States do not permit any change in wording of the TPP text, although side letters and binding interpretations will be available. Third, given the defensive nature of the TPP for most high-income country Parties (a fear of what they would lose if not part of the Agreement dominated by the United States) and the limited aggregate welfare gains ${ }^{[7]}$, it may be time for some of the Parties to simply say no, and to re-think and re-calibrate the purpose of such trade deals: To promote human well-being and development in a context of fragile and diminishing natural resources, or to increase the powers of investors and transnational corporations to accumulate capital.

\section{Acknowledgements}

The study was funded by the Canadian Institutes for Health Research (CIHR), Ottawa, ON, Canada through operating grant No. 133483.

\section{Ethical issues}

The study was approved by the Research Ethics Board of the University of Ottawa, Ottawa, ON, Canada.

\section{Competing interests}

Authors declare that they have no competing interests.

\section{Authors' contributions}

All authors participated in the methodological design, data collection, and analysis related to this paper. RL and AS drafted the initial manuscript. All authors read and approved the final manuscript.

\section{Endnotes}

[1] The TPP cannot come into force until one of the following conditions has been met: (1) all original signatories complete their domestic processes within 2 years of signing; (2) at least 6 countries complete their domestic processes within 2 years of signing and they account for at least $85 \%$ of the combined GDP of the original signatories; or (3) at least 6 countries complete their domestic processes and they account for at least $85 \%$ of the combined GDP of the original signatories. The United States accounts for $60 \%$ of the combined GDP of the original signatories, meaning the TPP cannot come into force without the United States.

[2] Countries can issue a compulsory license for drugs patented in its jurisdiction for the supply of a developing country if the recipient country can demonstrate evidence of a public health concern, evidence that the importer's pharmaceutical industry is non-existent or inadequate, and proof that the drug will be used only for public, non-commercial purposes.

[3] The Comprehensive Economic and Trade Agreement (CETA) between the European Union (EU) and Canada (still awaiting 'legal scrubbing' and ratification) offers some indication of what might be expected with the TPP. The EU is granting up to 5 years of patent term restoration (the CETA term for an extension), although Canada has only agreed to a maximum of 2 years. When the WTO TRIPS Agreement was reached, it was assumed that the 20 years of patent protection it afforded would be sufficient to account for any delays in government marketing approval.

[4] Economic Co-operation and Development (OECD) estimates from 2012 suggested that the cost was approximately US\$8 million for each side; however, this estimate is likely outdated as Australia reportedly paid US\$50 million to defend against Philip Morris Australia's claim against their tobacco plain packaging case ${ }^{36}$ a case that concluded at the jurisdiction phase. This number would likely have increased substantially if the case had proceeded to the merits phase.

[5] Some public health advocates are concerned that the TPP tobacco exclusion does not apply to state-to-state disputes. This may be an issue under TRIPS, one of the WTO Agreements cited in the remaining 4 country disputes against Australia's plain packing law, since how a dispute panel rules around whether Australia's law violates tobacco companies' intellectual property in their trademarks and brand names/differentiations remains to be seen. Generally, however, WTO dispute panels of late have been allowing health regulations considerable latitude, provided they are not obviously discriminatory.

[6] There are other weaknesses in the EC proposal, including its inclusion of FET provisions and its restriction of the 'right to regulate' by governments to 'legitimate policy objectives,' leaving again the determination of what constitutes legitimate not to public policy experts, but to its ICS judges whose qualifications are defined solely by their expertise in trade and investment law.

[7] The most widely cited estimate of TPP annual income gains (achieved only in 2025 ) average $0.5 \%$ of GDP across all 12 countries, only $0.2 \%$ more than the background trend. ${ }^{45} \mathrm{~A}$ recent study using different modelling assumptions estimated even lower economic gains alongside net employment losses. ${ }^{46}$ Estimates of trade-related welfare gains, which can affect health through the employment (or loss thereof) arising from new liberalisation commitments, vary widely according to the models used. In general, media reports of the expected gains of the TPP have been greatly exaggerated. ${ }^{47}$

\section{References}

1. Stoller M. Trans-Pacific Partnership: The biggest trade deal you've never heard of. Salon. http://www.salon.com/2012/10/23/ everything_you_wanted_to_know_about_the_trans_pacific partnership/. Accessed May 12, 2014. Published October 2012.

2. DePillis L. Everything you need to know about the Trans Pacific Partnership. The Washington Post. December 11, 2013. https:// www.washingtonpost.com/news/wonk/wp/2013/12/11/everythingyou-need-to-know-about-the-trans-pacific-partnership/. Accessed December 9, 2015.

3. Dollar D. Is globalization good for your health? Bull World Health Organ. 2001;79(9):827-833.

4. Baker P, Kay A, Walls H. Trade and investment liberalization and Asia's noncommunicable disease epidemic: a synthesis of data 
and existing literature. Glob Health. 2014;10(1):66.

5. Friel S, Gleeson D, Thow AM, et al. A new generation of trade policy: potential risks to diet-related health from the trans pacific partnership agreement. Glob Health. 2013;9(1):46.

6. Friel S, Hattersley L, Snowdon W, et al. Monitoring the impacts of trade agreements on food environments. Obes Rev. 2013;14:120-134. doi:10.1111/obr.12081

7. Labonte R, Sanger M. Glossary of the World Trade Organisation and public health: part 1. J Epidemiol Community Health. 2006;60(8):655-661. doi:10.1136/jech.2005.037895

8. Labonte R, Sanger, M. Glossary on the World Trade Organisation and public health: part 2. J Epidemiol Community Health. 2006;60(9):738-744. doi:10.1136/jech.2005.038950

9. Schram A, Labonté R, Sanders D. Urbanization and international trade and investment policies as determinants of noncommunicable diseases in Sub-Saharan Africa. Prog Cardiovasc Dis. 2013;56(3):281-301.

10. Schram A, Labonté R, Baker P, Friel S, Reeves A, Stuckler D. The role of trade and investment liberalization in the sugar-sweetened carbonated beverages market: a natural experiment contrasting Vietnam and the Philippines. Glob Health. 2015;11(1):1.

11. Thow AM, Snowdon W, Labonté $R$, et al. Will the next generation of preferential trade and investment agreements undermine prevention of noncommunicable diseases? A prospective policy analysis of the Trans Pacific Partnership Agreement. Health Policy. 2015;119(1):88-96.

12. Thow AM. Trade liberalisation and the nutrition transition: mapping the pathways for public health nutritionists. Public Health Nutr. 2009;12(11):2150-2158.

13. Hirono K, Haigh F, Gleeson D, et al. Is health impact assessment useful in the context of trade negotiations? A case study of the Trans Pacific Partnership Agreement. BMJ Open. 2016;6:e010339. doi:10.1136/bmjopen-2015-010339

14. Hirono K, Haigh F, Gleeson D, Harris P, Thow AM. Negotiating Healthy Trade in Australia: A Health Impact Assessment of the Proposed Trans-Pacific Partnership Agreement. Liverpool, NSW: Centre for Health Equity Training Research and Evaluation; 2015. http://hiaconnect.edu.au/research-and-publications/tpp_ hial. Accessed March 11, 2015.

15. Faunce TA. The Trans-Pacific Partnership Agreement: challenges for Australian health and medicine policies. Med $\mathrm{J}$ Aust. 2011;194(2):83-86.

16. European Centre for Health Policy. Health Impact Assessment: Main Concepts and Suggested Approach. Brussels: WHO Regional Office for Europe; 1999. http://www.euro.who.int/ document/PAE/Gothenburgpaper.pdf. Accessed December 9, 2015

17. Lee K, Ingram A, Lock K, Mclnnes C. Bridging health and foreign policy: the role of health impact assessments. Bull World Health Organ. 2007;85(3):207-211. doi:10.2471/BLT.06.037077

18. Khan U, Pallot R, Taylor D, Kanavos P. The Transatlantic Trade and Investment Partnership: International Trade Law, Health Systems and Public Health. London, United Kingdom: London School of Economics and Political Science; 2015. http://www. epha.org/IMG/pdf/LSE_study-TTIP_International_Trade_Law_ Health_Systems_and_Public_Health_website.pdf. Accessed February 21, 2016.

19. Kelsey J. New-generation free trade agreements threaten progressive tobacco and alcohol policies. Addiction. 2012;107(10):1719-1721. doi:10.1111/j.1360-0443.2012.03874.x

20. Kelsey J. Trans-Pacific Partnership agreement: a gold-plated gift to the global tobacco industry. Am J Law Med. 2013;39:237-264.

21. Ruckert A, Schram A, Labonté R. The Trans-Pacific Partnership Agreement: Trading away our health? Can J Public Health. 2015;106(4):e249-e251.

22. Schram A, Labonte R, Khatter K. The Trans-Pacific Partnership agreement and public health: why we should be concerned. Open Med. 2014;8(3):e100.

23. Buse K. Addressing the theoretical, practical and ethical challenges inherent in prospective health policy analysis. Health Policy Plan. 2008;23(5):351-360.

24. The Cost of Cancer Drugs. 60 Minutes. CBC news website. http://www.cbsnews.com/news/cost-of-cancer-drugs-60minutes-lesley-stahl-health-care/. Accessed December 9, 2015. Published October 2014.

25. Sachgau $O$. The price of being pain free: Why are life-changing biologics out of reach for so many? The Globe and Mail website. http://www.theglobeandmail.com/life/health-and-fitness/health/ the-price-of-being-pain-free-why-are-biologics-out-of-reachfor-so-many/article26332629/. Published September 13, 2015. Accessed December 9, 2015.

26. Mauldin W. U.S., Australia Agree on Complicated Compromise on Biologic Drugs. Wall Street Journal. October 4, 2015. http:// www.wsj.com/articles/u-s-australia-agree-on-complicatedcompromise-on-biologic-drugs-1443988019. Accessed February 21, 2016.

27. Beall R, Kuhn R. Trends in compulsory licensing of pharmaceuticals since the Doha Declaration: a database analysis. PLoS Med. 2012;9(1):e1001154. doi:10.1371/journal. pmed

28. Gleeson D. Commentary on the Leaked TPP Transparency Chapter Annex on Transparency and Procedural Fairness for Pharmaceutical Products and Medical Devices; 2015. https:// wikileaks.org/tpp/healthcare/Dr-Deborah-Gleeson-Analysison-TPP-Transparency-for-Healthcare-Annex.pdf. Accessed December 15, 2015.

29. Lexchin J, Mintzes B. A compromise too far: A review of Canadian cases of direct-to-consumer advertising regulation. Int J Risk Saf Med.2014;26(4):213-225.

30. Appellate Body. EC Measures Concerning Meat and Meat Products (hormones). World Trade Organization; 1998. https:// www.wto.org/english/tratop_e/dispu_e/hormab.pdf. Accessed February 21, 2016.

31. Suppan S. The TPP SPS Chapter: Not a "Model for the Rest of the World." Institute for Agriculture and Trade Policy; 2015. http://www.iatp.org/documents/the-tpp-sps-chapter-not-a$\%$ E2\%80\%9Cmodel-for-the-rest-of-the-world\%E2\%80\%9D. Accessed December 9, 2015.

32. Terry S. The Environment under TPPA Guidance. New Zealand Law Foundation; 2016. https://tpplegal.files.wordpress. com/2015/12/tpp-environment.pdf. Accessed February 21, 2016.

33. Palmberg E. The Insider List. Sojourners website. https://sojo. net/articles/insider-list. Accessed December 9, 2015. Published June 29, 2012

34. United Nations Conference on Trade and Development. Recent Trends in IIAs and ISDS. Geneva, Switzerland: United Nations Conference on Trade and Development; 2015. http://unctad.org/ en/PublicationsLibrary/webdiaepcb2015d1_en.pdfq. Accessed December 9, 2015.

35. Van Harten G. Sovereign Choices and Sovereign Constraints: Judicial Restraint in Investment Treaty Arbitration. United Kingdom: Oxford University Press; 2013.

36. Chapman S. Australian government's $\$ 50 \mathrm{~m}$ investment in defending against Big Tobacco legal thuggery. The Conversation website. http://theconversation.com/australian-governments$50 \mathrm{~m}$-investment-in-defending-against-big-tobacco-legalthuggery-45427. Accessed January 29, 2016. Published July 2015.

37. Tienhaara K. Regulatory chill and the threat of arbitration: a view from political science. In: Brown C, Miles K, eds. Evolution in Investment Treaty Law and Arbitration. United Kingdom: Cambridge University Press; 2011. 
38. Mann H. International Investment Agreements, Business and Human Rights: Key Issues and Opportunities. International Institute for Sustainable Development; 2008. http://www.iisd.org/ pdf/2008/iia_business_human_rights.pdf. Accessed February 21, 2016.

39. Eberhardt $P$, Olivet $C$. Profiting from Injustice: How Law Firms, Arbitrators and Financiers Are Fuelling an Investment Arbitration Boom. Brussels/Amsterdam: Corporate Europe Observatory and the Transnational Institute; 2012. http://www.tni.org/briefing/ profiting-injustice. Accessed March 25, 2014.

40. Bernasconi-Osterwalder N, Cosbey A, Johnson L, Vis-Dunbar D. Investment Treaties \& Why They Matter to Sustainable Development: Questions and Answers. International Institute for Sustainable Development; 2012. http://www.iisd.org/sites/ default/files/pdf/2011/investment_treaties_why_they_matter_ sd.pdf.

41. Johnson L, Sachs J. The TPP's Investment Chapter: Entrenching, rather than Reforming, a Flawed System. New York City: Columbia Center on Sustainable Investment; 2015. http:// ccsi.columbia.edu/files/2015/11/TPP-entrenching-flaws-21-NovFINAL.pdf. Accessed April 11, 2016.
42. Clayton and Bilcon v Government of Canada. (International Court of Justics). http://www.international.gc.ca/trade-agreementsaccords-commerciaux/assets/pdfs/disp-diff/clayton-13.pdf. Accessed December 9, 2015

43. Frenk J, Moon S. Governance challenges in global health. N Engl JMed.2013;368(10):936-942. doi:10.1056/NEJMra1109339

44. Kickbusch I, Gleicher D. Governance for Health in the 21st Century. Geneva, Switzerland: WHO; 2012. http://www.euro. who.int/en/publications/abstracts/governance-for-health-in-the21st-century. Accessed April 11, 2016.

45. Petri PA, Plummer MG. The Trans-pacific Partnership and Asia-Pacific Integration: Policy Implications. http://www.iie.com/ publications/pb/pb12-16.pdf. Accessed May 26, 2014. Published June 2012.

46. Capaldo J, IzurietaA, Sundaram J. Trading down: Unemployment, Inequality and Other Risks of the Trans-Pacific Partnership Agreement. Medford, MA: Tufts University; 2016. http://ase.tufts. edu/gdae/. Accessed January 20, 2016.

47. Schram A, Ruckert A, Miller B, Labonté R. Media and Neoliberal Hegemony: Canadian Newspaper Coverage of the Trans-Pacific Partnership Agreement. Stud Polit Econ. Forthcoming. 